\title{
No time for pending confirmation of invasive fungal disease in critically ill COVID-19 patients - think empirical treatment
}

\author{
Anne-Lise Bienvenu ${ }^{1,2^{*}}$ DD Nathalie Bleyzac ${ }^{1}$, Jean-Christophe Richard ${ }^{3}$ and Gilles Leboucher ${ }^{1}$
}

To the Editor,

In a recent study, Wang et al. [1] reported invasive pulmonary aspergillosis in patients with coronavirus disease 2019 (COVID-19), thus claiming for an early intervention with bronchoscopy and the importance of obtaining evidence of fungal microbiology in patients with severe/critical COVID-19. We fully agree on this point considering that invasive fungal infections (IFI), mostly invasive pulmonary aspergillosis, are increasingly reported in COVID-19 patients admitted in intensive care units (ICU); coronavirus-associated pulmonary aspergillosis (CAPA) was demonstrated to affect up to $30 \%$ of ventilated patients with COVID-19 [2]. Nevertheless, few issues should be addressed.

First, CAPA diagnosis is challenging. Questions remain if COVID-19 patients have a true invasive aspergillosis or are just colonized with Aspergillus in regards with serum galactomannan negativity [3]. Nevertheless, an independent association between CAPA and 30-day mortality was recently demonstrated using a multivariate logistic regression model among intubated patients [2], although a causal link remains to date unproven.

Second, the use of corticosteroids or anti-IL6 antibody in addition to standard of care is proposed for critically ill patients with COVID-19. But corticosteroids are wellknown risk factors for IFI and identified as a negative outcome predictor of invasive aspergillosis [4], whereas

\footnotetext{
* Correspondence: anne-lise.bienvenu@chu-lyon.fr

'Service Pharmacie, Groupement Hospitalier Nord, Hospices Civils de Lyon, 103 grande rue de la Croix-Rousse, 69004 Lyon, France

${ }^{2}$ ICBMS CNRS 5246, Campus Lyon-Tech La Doua, Université de Lyon, Lyon, France

Full list of author information is available at the end of the article
}

IFI were reported in patients treated with anti-IL6 antibody [5]. Thus, it is expected that incidence of IFI may increase with the more extensive use of corticosteroids or other immunomodulating therapies, and this, mostly in patients with risk factors for CAPA such as older age, initial antibiotic usage of beta-lactamase inhibitor combination, and chronic obstructive pulmonary disease (COPD) [1].

In this context, it is urgent to consider the opportunity of empirical use of antifungals without waiting for the final evidence of fungal microbiology, in case of a clinical suspicion of IFI. This is especially true for critically ill COVID-19 patients receiving immunomodulating therapies. Certainly, it will be most of the time an off-label use of antifungals in ICU patients, but what a prize to win under the emergency conditions of COVID-19 pandemic. Antifungal stewardship programs should support the implementation of such strategies, including the discontinuation of antifungals with negative mycological results and the impact assessment of antifungal use in terms of efficacy, safety, drug interactions, and resistance emergence.

\section{Abbreviations \\ CAPA: Coronavirus-associated pulmonary aspergillosis; COVID-19: Coronavirus disease 2019; ICU: Intensive care units; IFI: Invasive fungal infections;} COPD: Chronic obstructive pulmonary disease

\section{Acknowledgements}

Not applicable.

\section{Authors' contributions}

ALB has contributed to the conception of the manuscript and wrote the first draft. NB, JCR, and GL were major contributors in writing the manuscript. All authors read and approved the final manuscript.

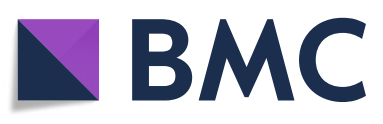

(c) The Author(s). 2020 Open Access This article is licensed under a Creative Commons Attribution 4.0 International License, which permits use, sharing, adaptation, distribution and reproduction in any medium or format, as long as you give appropriate credit to the original author(s) and the source, provide a link to the Creative Commons licence, and indicate if changes were made. The images or other third party material in this article are included in the article's Creative Commons licence, unless indicated otherwise in a credit line to the material. If material is not included in the article's Creative Commons licence and your intended use is not permitted by statutory regulation or exceeds the permitted use, you will need to obtain permission directly from the copyright holder. To view a copy of this licence, visit http://creativecommons.org/licenses/by/4.0/. The Creative Commons Public Domain Dedication waiver (http://creativecommons.org/publicdomain/zero/1.0/) applies to the data made available in this article, unless otherwise stated in a credit line to the data. 


\section{Funding}

None

Availability of data and materials

Not applicable.

Ethics approval and consent to participate

Not applicable.

\section{Consent for publication}

Not applicable.

\section{Competing interests}

The authors declare that they have no competing interests.

\section{Author details}

${ }^{1}$ Service Pharmacie, Groupement Hospitalier Nord, Hospices Civils de Lyon, 103 grande rue de la Croix-Rousse, 69004 Lyon, France. ${ }^{2}$ ICBMS CNRS 5246, Campus Lyon-Tech La Doua, Université de Lyon, Lyon, France. ${ }^{3}$ Service de réanimation médicale, Groupement Hospitalier Nord, Hospices Civils de Lyon, Lyon, France.

Received: 7 September 2020 Accepted: 22 September 2020

Published online: 29 September 2020

\section{References}

1. Wang J, Yang Q, Zhang P, Sheng J, Zhou J, Qu T. Clinical characteristics of invasive pulmonary aspergillosis in patients with COVID-19 in Zhejiang, China: a retrospective case series. Crit Care. 2020;24:299.

2. Bartoletti M, Pascale R, Cricca M, Rinaldi M, Maccaro A, Bussini L, et al. Epidemiology of invasive pulmonary aspergillosis among COVID-19 intubated patients: a prospective study. Clin Infect Dis. 2020. https://doi.org/ 10.1093/cid/ciaa1065.

3. Brüggemann RJ, van de Veerdonk FL, Verweij PE. The challenge of managing COVID-19 associated pulmonary aspergillosis. Clin Infect Dis. 2020. https://doi.org/10.1093/cid/ciaa1211.

4. Koehler P, Salmanton-García J, Gräfe SK, Koehler FC, Mellinghoff SC, Seidel $D$, et al. Baseline predictors influencing the prognosis of invasive aspergillosis in adults. Mycoses. 2019;62:651-8.

5. Campochiaro C, Della-Torre E, Cavalli G, De Luca G, Ripa M, Boffini N, et al. Efficacy and safety of tocilizumab in severe COVID-19 patients: a singlecentre retrospective cohort study. Eur J Intern Med. 2020;76:43-9.

\section{Publisher's Note}

Springer Nature remains neutral with regard to jurisdictional claims in published maps and institutional affiliations. 